\title{
Education law prevention for crime following and the impact of disabled against children
}

\author{
Marlina $^{1 *}$, Mahmud Mulyadi $^{1}$ \\ ${ }^{1}$ Faculty of Law, Universitas Sumatera Utara Medan \\ *Email: marlina@usu.ac.id
}

\begin{abstract}
Children as the next generation of national and state struggles will determine the success and progress of the nation in the future. The rise of internet development and promiscuity through face books, wa, instructors raises the concern that children will be involved in the crime of sexual abuse. Protection and attention of parents, family and government for the development and future of children. Protection and legal policies as well as supervision and the social system of the community are very helpful in efforts to prevent the crime of sexual abuse and the effects of molestation on children. In partner villages, there are many parents, community leaders, traditional leaders and village officials who do not know the limits of criminal acts of sexual abuse and the effects of molestation on children's development in the future. In addition, the natural conditions of the partner villages are abundant with forests and hamlets as well as residents' houses within distance and level low education and income of citizens causes a lack of attention to the growth and development of children. The team considers it important to do legal education in partner villages. The method is with lectures, tutorials and distributing guidebooks to the community related to the theme of devotion. The results of the dedication show that there are 148 community cadres in partner villages who already have legal understanding and legal awareness about the factors that cause the crime of sexual abuse, the legal provisions for criminal acts of crime, criminological theories that cause delinquency and the impact on children and the collaboration of all components of society, parents, government villages and sub-districts in prevention efforts.
\end{abstract}

Keyword: Legal Education, Sexual Abuse, Children.

\begin{abstract}
Abstrak
Anak sebagai generasi penerus perjuangan bangsa dan negara sangat menentukan keberhasilan dan kemajuan bangsa di masa depan. Maraknya perkembangan internet dan pergaulan melalui face book, wa, instragam memunculkan kekhawatiran anak akan terlibat tindak pidana pencabulan. Perlindungan dan perhatian orang tua, keluarga dan pemerintah demi perkembangan dan masa depan anak. Perlindungan dan kebijakan hukum serta pengawasan dan sistem sosial masyarakat sangat membantu dalam upaya pencegahan tindak pidana pencabulan dan dampak pencabulan bagi anak. Di desa mitra banyak orang tua, pemuka masyarakat, pemuka adat dan aparat desa yang belum mengetahui batasan tindak pidana pencabulan dan dampak pencabulan terhadap perkembangan anak di masa depan, Selain itu kondisi alam desa mitra yang banyak hutan dan dusun serta rumah penduduk yang berjarak serta tingkat pendidikan dan penghasilan warga yang rendah menyebabkan kurangnya perhatian terhadap pertumbuhan dan perkembangan anak. Tim menganggap penting dilakukan Pendidikan hukum di desa mitra. Metodenya dengan ceramah, tutorial serta membagikan buku panduan kepada masyarakat terkait tema pengabdian. Hasil pengabdian menunjukan ada 148 kader masyarakat di desa mitra yang telah memiliki pemahaman hukum dan kesadaran hukum tentang faktor penyebab tindak pidana pencabulan, ketentuan hukum indak pidana pencabulan, teori kriminologi penyebab delinkuensi dan dampak terhadap anak serta adanya kerjasama semua komponen masyarakat, orang tua, pemerintahan desa dan kecamatan dalam upaya pencegahan.
\end{abstract}

Keyword: Pendidikan Hukum, Pencabulan, Anak.

\section{PENDAHULUAN}


Pembuatan Anak adalah anugerah dari Tuhan Yang Maha Esa yang harus mendapatkan perhatian khusus terhadap pertumbuhan dan perkembangannya. Anak harus dilindungi hak-haknya, bahkan diberikan perlakuan khusus terhadap situasi-situasi tertentu yang dihadapi anak demi masa depannya.

Anak sebagai generasi penerus bangsa pemegang tongkat estafet perjuangan bangsa dan negara dimasa yang akan datang. Anak menjadi harapan besar kemajuan dan keruntuhan suatu bangsa secara luas dan keruntuhan keluarga secara khususnya. Harapan Negara dan harapan keluarga selalu di tanggan anak, bahkan banyak pernyataan mengatakan hidup tanpa harta menjadi sedih, namun akan sangat lebih sedih hidup tampa anak (keturunan) di masa depan yang akan memegang garis keturunan keluarga.

Besarnya harapan pada anak menuntut anak menjadi sosok mahluk yang sangat di lindungi dan diperhatikan tumbuh kembangnya. Baik buruknya masa depan bangsa tergantung pada baik buruknya kondisi anak saat ini,Maju tidaknya suatu bangsa akan sangat di tentukan cerdas dan terampilnya anak saat ini. Perlakuan terhadap anak dengan cara yang baik adalah kewajiban kita bersama agar anak bisa tumbuh berkembang dengan baik dan dapat menjadi pengemban risalah peradaban bangsa ini.

Secara tegas esensi penting seorang anak dirumuskan dalam pertimbangan Undang-Undang No. 35 Tahun 2014 tentang Perubahan Atas Undang-Undang No. 23 Tahun 2002 tentang Perlindungan Anak. Butir c menyatakan bahwa "bahwa anak sebagai tunas, potensi, dan generasi muda penerus cita-cita perjuangan bangsa memiliki peran strategis, ciri, dan sifat khusus sehingga wajib dilindungi dari segala bentuk perlakuan tidak manusiawi yang mengakibatkan terjadinya pelanggaran hak asasi manusia".

Selanjutnya dalam Pasal 2 Undang-Undang No. 35 Tahun 2014 menyatakan bahwa adalah "segala kegiatan untuk menjamin dan melindungi Anak dan hak-haknya agar dapat hidup, tumbuh, berkembang, dan berpartisipasi secara optimal sesuai dengan harkat dan martabat kemanusiaan, serta mendapat perlindungan dari kekerasan dan diskriminasi". Ketentuan ini menunjukan bahwa anak sangat penting untuk diberikan perlindungan terhadap hak-haknya terkait tumbuh kembang anak di masa yang akan datang.

Perlindungan hukum memiliki peranan penting meninggat pesatnya dampak negatif dari perkembangan teknologi dan informasi yang mengubah pola dan gaya hidup anak. Anak dengan sangat mudahnya mengakses bacaan-bacaan dan film-film yang berkontens memuat porno masuk dan muncul melalui ponsel-ponselnya. Media cetak dengan mudah didapatkan anak untuk membacanya terkait kontes seksual, kekerasan dan pornografi yang belum sesuai dengan perkembangan anak. Kondisi ini akan menimbulkan penurunan moral dan pemikiran negatif bagi perkembangan anak, anak akan berkhayalan dan berimajinasi sehingga membuat anak penasaran ingin tahu sehingga memicu anak mempraktikkan hal tersebut.

Pencabulan adalah perbuatan cabul, yaitu segala perbuatan yang melanggar kesusilaan (kesopanan) atau perbuatan yang keji, semuanya itu dalam lingkungan nafsu berahi kelamin, misalnya cium-ciuman, meraba-raba anggota kemaluan, meraba-raba buah dada dan sebagainya. Persetubuhan masuk dalam pengertian perbuatan cabul, akan tetapi dalam undang-undang disebutkan tersendiri.Menurut Shanty Delyana bahwa Perlindungan Anak harus diusahakan dalam berbagai bidang kehidupan bernegara dan bermasyarakat.

Penyimpangan tingkah laku atau perbuatan melanggar hukum yang dilakukan anak disebabkan berbagai faktor, diantaranya dampak negatif dari perkembangan informasi, arus globalisasi di bidang komunikasi dan informasi serta perubahan gaya dan cara hidup membawa perubahan sosial yang mendasar dalam kehidupan masyarakat. Selain itu anak yang kurang atau tidak memperoleh kasih sayang, asupan bimbingan dan pembinaan dalam pengembangan sikap, prilaku penyesuai diri serta pengawasan dari orang tua wali, atau orang tua asuh dan pergaulan lingkungan masyarakat yang kurang sehat juga menyebabkan seseorang anak dapat terjerumus dalam kejahatan. 
Anak yang Berkonflik dengan hukum adalah anak yang telah berumur 12 (dua belas) tahun, tetapi belum berumur 18 (delapan belas) tahun yang diduga melakukan tindak pidana." Anak adalah seseorang yang belum berusia 18 (delapan belas) tahun, termasuk anak yang masih dalam kandungan. Anak adalah setiap manusia yang berusia di bawah 18 (delapan belas) tahun dan belum menikah, termasuk anak yang masih dalam kandungan apabila hal tersebut adalah demi kepentingannya."

Berdasarkan uraian diatas tim pengabdian masyarakat dalam tugasTri Darma Perguruan Tinggi mengadakan Pendidikan Hukum Tentang Pencegahan Tindak Pidana Pencabulan dan Dampak Pencabulan Terhadap Anak di Desa Suka Dame Kecamatan Kutalimbaru Deli Serdang.

\section{METODE PELAKSANAAN}

Kegiatan dilaksanakan di Desa Suka Dame Kecamatan Kutalimbaru Deli Serdang. Pemilihan lokasi dilakukan secara proposive. Desa Suka Dame sebuah desa yang letaknya di Kecamatan Kutalimbaru Kabupaten Deli Serdang Sumatera Utara, yang mayoritas 90\% beragama kristen dan sisa Islam. Pendudukan rata-rata memiliki pekerjaan bertani dan berladang serta berdagang. Suku yang ada suku Karo, Batak, dan sebagian Jawa dan Minang. Kehidupan masyarakatnya sangat komplek, tingkat Pendidikan masih rendah. Homogennya penduduk dan kompleknya mata pencaharian sehingga masyarakat masih minim keinginan untuk memantau pergaulan dan pendidikan anak-anak, bahkan orang tua membiarkan anak-anaknya pulang sekolah naik kendaraan umum yang berbahaya untuk anak karena kondisi alam desa yang luas, sepi, banyak hutan serta jalannya jelek. Kondisi ini menyebabkan anak-anak di khawatirkan memiliki peluang terlibat tindak pidana pencabulan dan dampak pencabulan dalam perkembangannya. Adapun metode kegiatan yang dilakukan yaitu dengan pelatihan dengan Ceramah dan tutorial kepada kelompok masyarakat secara berkala tentang Ketentuan Hukum Tindak Pidana Pencabulan, Faktor penyebab anak melakukan prilaku menyimpang dan Upaya orang tua dalam mencegah anak serta Dampak tindak pidana narkotika terhadap anak di Desa tersebut. Dilanjutkan dengan pembagian Buku Pedoman untuk mempermuda dalam pemahaman, kemudian dilakukan diskusi dan evaluasi terhadap materi yang telah disampaikan kepada masyarkat mengenai pemahaman hukum masyarakat. Tahapan berikutnya melakukan konsultasi dan pendampingan terhadap kasus yang dihadapi oleh masyarakat di desa mitra di dalam proses pengabdian baik di waktu pengabdian yang sedang berlangsung, maupun di luar waktu pengabdian.

\section{HASIL DAN PEMBAHASAN}

Pengabdian Pendidikan Hukum Tentang Pencegahan Tindak Pidana Pencabulan dan Dampak Pencabulan Terhadap anak yang dilakukan di Desa Suka Dame Kecamatan Kutalimbaru yang dilaksanakan sejak bulan Juni sampai dengan Oktober di ikuti oleh 148 kader masyarkat, unsur pimpinan desan dan pemuka masyarakat berupa peningkatan pemahaman hukum mengenai:

\subsection{Pengaturan Tindak Pidana Pencabulan dalam Peraturan Perundang-Undangan \\ A. Kitab Undang-Undang Hukum Pidana}

1) Perkosaan

KUHP merumuskan perbuatan perkosaan pada pasal 285 yang bunyinya sebagai berikut. "Barangsiapa dengan kekerasan atau ancaman kekerasan memaksa seorang wanita bersetubuh dengan dia di luar perkawinan, diancam karena melakukan perkosaan, dengan pidana penjara paling lama dua belas tahun."

Berdasarkan pasal 291 ayat (2), jika perkosaan tersebut mengakibatkan matinya perempuan itu, ancaman menjadi lima belas tahun penjara.

Orang yang diancam hukuman dalam pasal 285 ini ialah dengan kekerasan atau ancaman kekerasan memaksa perempuan yang bukan isterinya untuk bersetubuh dengan dia. 
Seorang perempuan yang dipaksa demikian rupa, sehingga akhirnya tak dapat melawan lagi dan terpaksa mau melakukan persetubuhan itu, masuk pula dalam pasal ini. "Persetubuhan" harus benar-benar dilakukan, apabila tidak, mungkin dapat dikenakan pasal 289 yang mengatakan tentang "perbuatan cabul".

Tentang kekerasan dapat dilihat pada pasal 89, yaitu: "Membuat orang pingsan atau tidak berdaya disamakan dengan menggunakan kekerasan."

2) Bersetubuh dengan wanita pingsan, di luar perkawinan

KUHP merumuskan hal ini pada pasal 286 yang bunyinya sebagai berikut.

"Barangsiapa bersetubuh dengan seorang wanita itu dalam keadaan pingsan atau tidak berdaya, diancam dengan pidana penjara paling lama sembilan tahun."

Kata "pingsan" disinonim dengan kata-kata "tidak sadar", "tidak ingat", sedang kata "tidak berdaya" adalah "tidak bertenaga" atau "sangat lemah"; kata "di luar perkawinan" dimaksudkan bahwa wanita tersebut, bukan istrinya.

Perbuatan yang dirumuskan pasal 286 KUHP tersebut secara rasional memang sangat sulit dibuktikan terutama karena wanita yang disetubuhi, jika dalam keadaan pingsan, tidak dapat dijadikan saksi, lebih rumit lagi jika sebelum sadarkan diri telah ditinggalkan pria yang menyetubuhinya, sedang orang lain yang menyaksikan kejadian sulit diharapkan karena pada umumnya persetubuhan berlangsung tanpa kehadiran orang lain.

3) Bersetubuh dengan wanita yang belum dewasa

KUHP merumuskan hal ini pada pasal 287 KUHP yang bunyinya sebagai berikut.

(a) Barang siapa bersetubuh dengan seorang wanita di luar perkawinan, diketahui atau sepatutnya harus diduga bahwa umurnya belum lima belas tahun atau kalau umurnya tidak ternyata bahwa belum mampu dikawin, diancam dengan pidana penjara paling lama sembilan tahun.

(b) Penuntutan hanya dilakukan atas pengaduan kecuali jika umurnya wanita belum sampai dua belas tahun atau jika ada salah satu hal tersebut pada pasal 291 dan pasal 294."

Menurut pasal 291 KUHP, ancaman hukuman diperberat menjadi 12 tahun jika mengakibatkan luka parah dan 15 tahun, jika mengakibatkan mati. Jika hanya "persetubuhan" dengan wanita yang berumur belum 15 tahun tetapi telah di atas 12 tahun, yang tidak mengakibatkan luka parah atau mati, maka berdasarkan ayat (2) merupakan delik aduan.

Kecermatan diperlukan pada penerapan pasal 287 khususnya unsur kesalahan yang dirumuskan dengan "diketahui atau patut dapat menduga". Maksudnya, si pria secara layak/wajar dapat menduga bahwa umur wanita tersebut belum 15 tahun. Jika tubuh si wanita seperti wanita dewasa maka akan sulit mempermasalahkannya.

4) Perbuatan cabul dengan kekerasan/ancaman kekerasan

KUHP merumuskan hal ini pada pasal 289, sebagai berikut.

"Barangsiapa dengan kekerasan atau dengan ancaman kekerasan memaksa seseorang melakukan atau membiarkan dilakukan padanya perbuatan cabul, dihukum karena salahnya melakukan perbuatan melanggar kesopanan dengan hukuman penjara selamalamanya sembilan tahun."

5) Perbuatan cabul dengan orang pingsan

KUHP merumuskan hal ini pada pasal 290 ke-1 yang rumusannya sebagai berikut.

"Diancam dengan pidana penjara paling lama tujuh tahun: barangsiapa melakukan perbuatan cabul dengan seorang, padahal diketahuinya bahwa orang itu pingsan atau tidak berdaya." Kata "diketahuinya" adalah rumusan dolus atau sengaja. Dengan demikian si pelaku mengetahui bahwa yang dicabulinya tersebut, dalam keadaan pingsan atau tidak berdaya.

6) Perbuatan cabul dengan orang yang belum 15 tahun.

KUHP merumuskan hal ini pada pasal 290 ke-2 sebagai berikut. 
"Diancam dengan pidana penjara paling lama tujuh tahun:"barangsiapa melakukan perbuatan cabul dengan seorang, padahal diketahuinya atau sepatutnya harus diduganya, bahwa umurnya belum lima belas tahun atau kalau umurnya tidak jelas, yang bersangkutan belum waktunya untuk dikawin."

Pasal ini merupakan perlindungan terhadap anak/remaja. Perlu diperhatikan bahwa pada pasal tersebut tidak ada kata "wanita" melainkan kata "orang", dengan demikian meskipun dilakukan terhadap anak/remaja pria, misalnya oleh homoseks atau yang disebut sehari-hari oleh "tante girang" maka pasal ini dapat diterapkan. Tetapi jika sejenis maka hal itu diatur pasal 292 KUHP.

7) Membujuk orang yang belum dewasa untuk berbuat cabul atau bersetubuh dengan orang lain.

KUHP merumuskan hal ini pada pasal 290 ke-3, yaitu sebagai berikut.

"Diancam dengan pidana penjara paling lama tujuh tahun:"barangsiapa membujuk seseorang yang diketahuinya atau sepatutnya harus diduganya bahwa umurnya belum lima belas tahun atau kalau umurnya tidak jelas yang bersangkutan belum waktunya untuk dikawin, untuk melakukan atau membiarkan dilakukan perbuatan cabul, atau bersetubuh di luar perkawinan dengan orang lain."

Pasal ini merupakan perlindungan terhadap anak-anak, baik anak wanita maupun anak pria. Rumusan umur "belum lima belas tahun" tidak terlepas dari pasal 45 KUHP.

Rumusan pasal 290 ke-3 tersebut, yang perlu dijelaskan adalah kata "membujuk". Kata "membujuk" dimuat pada pasal 55 ayat (1) ke-2 KUHP, tetapi membujuk dalam pengertian pasal 55 ayat (1) ke-2 dimaksudkan "untuk berbuat" bukan untuk "membiarkan dilakukan". Tampaknya pasal 55 ayat (1) ke-2 mensyaratkan "aktif" sedang "membujuk" yang dirumuskan pasal 290 ke-3 KUHP dapat bersifat "aktif" dan dapat juga "pasif". Jika si pelaku "pasif" maka hal itu tidak mungkin dalam persepsi pasal 55 ayat (1) ke-2 KUHP.

\section{B. Undang-Undang No. 35 Tahun 2014 Tentang Perubahan Atas Undang-Undang No. 23 Tahun 2002 Tentang Perlindungan Anak}

Sesuai dengan asas lex specialis derogat legi generali, artinya hukum yang bersifat khusus mengesampingkan hukum yang bersifat umum. Pelaku akan diadili berdasarkan ketentuan KUHP sekalipun tindak pidana pencabulan terhadap anak diatur di dalamnya KUHP, tetapi pelaku akan dikenakan ketentuan UU No. 35 Tahun 2014 tentang Perubahan Atas UU No. 23 Tahun 2002 tentang Perlindungan Anak.

UU No. 35 Tahun 2014 yang mengatur mengenai tindak pidana pencabulan terdapat pada pasal 76D dan pasal 76E, yaitu sebagai berikut:

1) Pasal 76D, berbunyi:

"Setiap orang dilarang melakukan kekerasan atau ancaman kekerasan memaksa anak melakukan persetubuhan dengannya atau dengan orang lain."

2) Pasal 76E, berbunyi:

"Setiap orang dilarang melakukan kekerasan atau ancaman kekerasan, memaksa, melakukan tipu muslihat, melakukan serangkaian kebohongan, atau membujuk anak untuk melakukan atau membiarkan dilakukan perbuatan cabul.”

\section{Undang-Undang No. 23 Tahun 2004 tentang Penghapusan Kekerasan Dalam Rumah Tangga}

Menurut Pasal 2 UU No. 23 Tahun 2004 bahwa lingkup rumah tangga menurut undangundang ini meliputi suami, istri, dan anak; orang-orang yang mempunyai hubungan keluarga karena hubungan darah, perkawinan, persusunan, pengasuhan dan perwalian, yang menetap dalam rumah tangga; dan/atau orang yang bekerja membantu rumah tangga dan menetap dalam rumah tangga tersebut. 
UU No. 23 Tahun 2004 tidak menyebutkan pasal yang secara khusus mengatur mengenai tindak pidana pencabulan, namun terdapat pasal yang memiliki jiwa yang sama untuk melindungi orang dari perbuatan cabul, yaitu sebagai berikut.

1) Pasal 46, berbunyi:

"Setiap orang yang melakukan perbuatan kekerasan seksual sebagaimana dimaksud pasa pasal 8 huruf a dipidana dengan pidana penjara paling lama 12 (dua belas) tahun atau denda paling banyak Rp. 36.000.000.00,- (tiga puluh enam juta rupiah)."

2) Pasal 47, berbunyi:

"Setiap orang yang memaksa orang yang menetap dalam rumah tangganya melakukan hubungan seksual sebagaimana dimaksud dalam pasal 8 huruf $\mathrm{b}$ dipidana dengan pidana penjara paling singkat 4 (empat) tahun dan pidana penjara paling lama 15 (lima belas) tahun atau denda paling sedikit Rp. 12.000.000.00,- (dua belas juta rupiah) atau denda paling banyak Rp. 300.000.000.00,- (tiga ratus juta rupiah).

Ketentuan pasal 8 yang disebutkan di atas, berbunyi:

"Kekerasan seksual sebagaimana dimaksud dalam pasal 5 huruf c meliputi:

(a) pemaksaan hubungan seksual yang dilakukan terhadap orang yang menetap dalam lingkup rumah tangga tersebut;

(b) pemaksaan hubungan seksual terhadap salah seorang dalam lingkup rumah tangganya dengan orang lain untuk tujuan komersial dan/atau tujuan tertentu."

Ketentuan pasal 5 huruf (c) yang disebutkan pada pasal 8 di atas, berbunyi:

"Setiap orang dilarang melakukan kekerasan dalam rumah tangga terhadap orang dalam lingkup rumah tangganya dengan cara:
a. kekerasan fisik;
b. kekerasan psikis;
c. kekerasan seksual; atau
d. penelantaran rumah tangga."

3) Pasal 48, berbunyi:

"Dalam hal perbuatan sebagaimana dimaksud dalam pasal 46 dan pasal 47 mengakibatkan korban mendapat luka yang tidak memberi harapan akan sembuh sama sekali, mengalami gangguan daya pikir, atau kejiwaan sekurang-kurangnya selama 4 (empat) minggu terus menerus atau 1 (satu) tahun tidak berturut-turut, gugur atau matinya janin dalam kandungan, atau mengakibatkan tidak berfungsinya alat reproduksi, dipidana dengan pidana penjara paling singkat 5 (lima) tahun dan pidana penjara paling lama 20 (dua puluh) tahun atau denda paling sedikit Rp. 25.000.000.00,- (dua puluh lima juta rupiah) dan denda paling banyak Rp. 500.000.000.00,- (lima ratus juta rupiah).

\subsection{Faktor Penyebab Tindak Pidana Menurut teori Kriminologi}

Secara teori ada 2 (dua) kategori perilaku anak yang membuat ia harus berhadapan dengan hukum, yaitu:

1) Status offence adalah perilaku kenakalan anak yang apabila dilakukan oleh orang dewasa tidak dianggap sebagai kejahatan, seperti tidak menurut, membolos sekolah atau kabur dari rumah;

2) Juvenile Delinquency adalah perilaku kenakalan anak yang apabila dilakukan orang dewasa dianggap kejahatan atau pelanggaran hukum.

Tindak pidana yang dilakukan oleh anak terlalu ekstrim disebut dengan kejahatan, karena anak memiliki kondisi kejiwaan yang labil, proses kemantapan psikis sehingga bersifat kritis, agresif dan menunjukkan tingkah laku yang cenderung bertindak mengganggu ketertiban umum. Tindak ini merupakan melainkan kenakalan yang ditimbulkan akibat dari kondisi psikologis yang tidak seimbang dan si pelaku belum sadar dan mengerti atas tindakan yang telah dilakukan anak. 
Kenakalan anak disebut juga dengan juvenile deliquency. Juvenile (dalam bahasa Inggris) atau yang dalam bahasa Indonesia berarti anak-anak; anak muda, sedangkan deliquency menurut Kamus Besar Bahasa Indonesia, delikuensi diartikan sebagai tingkah laku yang menyamai secara ringan norma dan hukum yang berlaku dalam suatu masyarakat.

Suatu perbuatan dikatakan delinkuen apabila perbuatan-perbuatan tersebut bertentangan dengan norma yang ada dalam masyarakat dimana ia hidup atau suatu perbuatan yang anti sosial yang di dalamnya terkandung unsur-unsur anti normatif.

Menurut Kartini Kartono ialah perilaku jahat (dursila), atau kejahatan/kenakalan anakanak muda; merupakan gejala sakit (patologis) secara sosial pada anak-anak dan remaja yang disebabkan oleh satu bentuk pengabaian sosial, sehingga mereka itu mengembangkan bentuk tingkah laku yang menyimpang.

Juvenile delinquency menurut Romli Atmasasmita adalah setiap perbuatan atau tingkah laku seseorang anak di bawah umur 18 tahun dan belum kawin yang merupakan pelanggaran terhadap norma-norma hukum yang berlaku serta dapat membahayakan perkembangan pribadi si anak yang bersangkutan.

Kejahatan remaja yang merupakan gejala penyimpangan dan patologis secara sosial mempunyai sebab-musabab yang majemuk; jadi sifatnya multi-kausal. Para sarjana menggolongkannya menurut beberapa teori, sebagai berikut:

1) Teori Biologis

Tingkah laku sosiopatik atau delinkuen pada anak-anak dan remaja dapat muncul karena faktor-faktor fisiologis dan struktur jasmaniah seseorang, juga dapat cacat jasmaniah yang dibawa sejak lahir.

2) Teori Psikologis

Teori tingkah laku delinkuen anak-anak dari aspek psikologis atau isi kejiwaannya, antara lain faktor inteligensi, ciri kepribadian, motivasi, sikap-sikap yang salah, fantasi, rasionalisasi, internalisasi diri yang keliru, konflik batin, emosi yang kontroversial, kecenderungan psikopatologis, dan lain-lain.

3) Teori Sosiologis

Penyebab tingkah laku delinkuen pada anak-anak remaja ini adalah murni sosiologis atau sosial-psikologis sifatnya, misalnya disebabkan oleh pengaruh struktur sosial yang deviatif, tekanan kelompok, peranan sosial, status sosial atau oleh internalisasi simbolis yang keliru.

4) Sutherland mengembangkan teori asosiasi diferensial.

Penyebab anak dan para remaja menjadi delinkuen karena partisipasinya di tengah-tengah suatu lingkungan sosial, yang ide dan teknik delinkuen tertentu dijadikan sarana yang efisien untuk mengatasi kesulitan hidupnya. Semakin lama anak bergaul dan semakin intensif relasinya dengan anak-anak jahat lainnya, akan menjadi semakin lama pula proses berlangsungnya asosiasi diferensial tersebut dan semakin besar kemungkinan anak-anak remaja tadi benar-benar menjadi kriminal.

\subsection{Faktor-Faktor Penyebab Tindak Pidana Pencabulan}

1) Faktor Internal (dalam diri anak sendiri) yaitu:

(a) Faktor Biologis dan Usia

Stephen Hurtwitz mengungkapkan "age is importance factor in the causation of crime" (usia adalah faktor yang penting dalam sebab musabab timbulnya kejahatan. tidak terkecuali kenakalan yang dilakukan oleh seorang anak.

(b) Belum Menemukan Jati Diri

Masa remaja adalah masa peralihan dari anak-anak menuju dewasa. Pada masa ini, frekuensi kejahatan tinggi terjadi konflik antara harapan dan kenyataan. Gejala kenakalan anak terungkap apabila meneliti bagaimana ciri-ciri khas atau ciri-ciri umum yang menonjol pada tingkah laku anak-anak puber, yakni pencarian suatu identitas 
kedewasaan cenderung melepaskan diri dari identitas maupun identifikasi lama dan mencari aku "ideal" sebagai identitas baru serta substitusi identitas lama.

(c) Rasa Ingin Tahu

Otak manusia, terutama laki-laki dibangun dengan dasar rasa ingin tahu, terlebih yang sudah menjurus pada lawan jenis. Godaan untuk melihat, mengintip, dan mencuri pandang sudah ada dalam darah laki-laki dan sulit untuk dilawan.

2) Faktor Eksternal

(a) Faktor Keluarga

Hubungan kedua orangtua yang telah bercerai sehingga anak diasuh oleh anggota keluarga lain mengakibatkan anak tidak mendapatkan perhatian dan pengawasan yang cukup dalam pergaulannya. Pengaruh keluarga berantaran dan broken home.

(b) Faktor Pendidikan

Sekolah adalah media atau perantara bagi pembinaan jiwa anak atau sekolah ikut bertanggung jawab terhadap pendidikan anak, baik pendidikan keilmuan maupun pendidikan tingkah laku (character).

Anak delinkuen pada dasarnya tingkat intelegensia verbal lebih rendah dan ketinggalan dalam pencapaian hasil-hasil skolastik (prestasi sekolah rendah). Dengan kecerdasan yang rendah dan wawasan sosial yang kurang tajam, mereka mudah sekali terseret oleh ajakan buruk untuk melakukan perilaku jahat.

(c) Pornografi melalui mass media

Menurut Marc Ancel, mass media adalah sebagai salah satu sarana yang digunakan untuk melakukan pencegahan kejahatan namun mass media justru berpengaruh terhadap timbulnya suatu kenakalan. Anak yang bacaan yang buruk, menonton porno akan memberikan rangsangan seks terhdap anak. Rangsangan seks tersebut akan berpengaruh negatif terhadap perkembangan anak.

(d) Perkembangan Teknologi Informasi

Anak dapat dengan mudah mengakses internet dan menerima informasi-informasi negatif tersebut. Berbagai bentuk pornografi dapat diakses dengan menggunakan internet dari warnet ataupun telepon genggam.

\subsection{Upaya yang dilakukan dalam pencegahan tindak pidana pencabulan ada du acara yaitu dengan}

\section{a. Penyuluhan Kesadaran Hukum bagi Anak dan Orang Tua}

Generasi muda/anak remaja merupakan bagian dari masyarakat yang berhak untuk memperoleh penyuluhan tentang kesadaran hukum. sehingga mereka mengerti hukum, menghargainya dan mampu mematuhi hukum. Sistem hukum yang harus diketahui, dihayati dan dipatuhi oleh anak remaja tidak hanya terbatas hukum tertulis, misalnya KUHP dan Undang-Undang, akan tetapi yang lebih luas yang di dalamnya mencakup hukum adat serta norma-norma yang tumbuh dan berkembang di dalam masyarakat.

\section{b. Razia yang Berkesinambungan}

Razia yang berkesinambungan oleh aparat keamanan/aparat penyidik terhadap buku/tulisan/kaset video porno, film porno, minuman keras, sangat besar artinya. Berkesinambungan dimaksudkan selain menghilangkan harapan para oknum untuk memperoleh untung dari benda-benda tersebut juga untuk menunjukkan kepada orang yang memproduksikannya, bahwa di Indonesia benda-benda tersebut, tidak mungkin dipasarkan.

\section{c. Peranan Sekolah (Pendidikan)}

Undang-Undang RI No. 2 Tahun 1989 tentang Sistem Pendidikan Nasional, Pasal 4 menegaskan, pendidikan nasional bertujuan mencerdaskan kehidupan bangsa dan mengembangkan manusia Indonesia seutuhnya, yaitu manusia beriman dan bertaqwa kepada Tuhan Yang Maha Esa dan berbudi pekerti luhur, memiliki pengetahuan dan keterampilan, kesehatan jasmani dan rohani, kepribadian yang mantap dan mandiri, serta rasa tanggung jawab kemasyarakatan dan kebangsaan. 
Mewujudkan lingkungan sekolah yang sehat dimulai dari menetapkan peraturan tentang pakaian seragam dengan maksud agar kehidupan peserta didik tampak serasi, tidak terjadi penonjolan kemewahan di antara mereka, dididik untuk hidup sederhana agar tidak suka berfoya-foya di lingkungan sekolah khususnya. Operasi tertib di lingkungan sekolah secara kontinu untuk menghilangkan sumber-sumber kenakalan remaja dengan kerjasama pihak keluarga peserta didik di rumah akan memotivasi prestasi dan disiplin pelajar. Pendidik harus memberikan tauladan kepada siswa dan menjadi sahabat pelajar dalam mengatasi kesulitan lainnya.

\section{d. Peranan Orang Tua (Keluarga)}

Keluarga sebagai tempat sosialisasi pencegahan kenakalan anak, maka di dalam keluarga memprioritaskan pada kebutuhan dan kesejahteraan keluarga dan semua anggotanya. Keluarga merupakan unit utama yang bertanggung jawab atas sosialisasi pencegahan kenakalan anak.

\section{e. Peranan Media Massa}

Penayangan televisi berita tentang kejahatan terhadap kesusilaan, sangat berarti untuk menumbuhkan kehati-hatian anggota masyarakat. Penayangan pada televisi atau pemuatan berita tentang putusan pengadilan, tidak kurang pentingnya untuk mengingatkan anggota masyarakat.

\section{f.Antisipasi Dampak Kemajuan Teknologi}

Teknologi adalah perkembangan yang niscaya kemunculannya seringkali tidak manusiawi. Oleh karena itu dibutuhkan antisipasi agar kehidupan manusia tetap berjalan sebagaimana yang diharapkan. Ini dengan catatan hanya menekan dampak negatif karena menghilangkannya adalah tidak mungkin.

\subsection{Luaran yang dihasilkan}

Setelah melaksanakan pengabdian di lokasi, maka diperoleh beberapa kegiatan yang dimuat dalam media promosi berupa buku pedoman, video kegiatan serta jurnal.

a. Buku Pedoman

Memuat tentang pengaturan tindka pidana pencabulan, factor penyeban tindak pidna pencabulan, teori delinkuensi pada anak, dnaupaya yang idlakukan dalam pencegahan tindk pidana pencabulan.

b. Vidio Kegiatan.

Vidio ini merupakan kumpulan kegiatan pengabdian yang dilakukan oleh tim pengandian dengan melibatkan masyarkat dan tokoh masyarakan dlam upaa untuk memberikan pemahaman Pendidikan hukum pencegahan tindak pidana pencabulan dan dampak pencabulan terhadap anak.

c. Jurnal ilmiah.

Jurnal tersebut sebagai bentuk promise terkait dengan pengabidana yang meliputi latar belakang dilaksanakannya kegiatan situasi kondisi lignkunan, metode kegiatan yand dilakukan serta hasil dari pengabdian yang dilakukan.

\section{KESIMPULAN}

Pelaksanaan Pengabdian masyarakat di Desa Suka Dame Kecamatan Kutalimbaru telah dilaksanakan sesuai dengan jadwal yang telah di rencanakan. Hasil evaluasi yang dilakukan kepada mitra menunjukan bahwa pengabdian yang telah dilakukan oleh tim pengabdian telah tercapai sesuai dengan tujuan yang di kehendaki. Mitra (masyarakat) telah memahami materi-materi pengabdian yang telah di lakukan dan dibukukan dalam buku pedoman oleh tim pengabdian masyarakat. Masyarakat di tempat mitra juga bersepakat untuk melakukan tindakan pencegahan tindak pidana pencabulan melalui kegiatan-kegiatan keagamaan dan olah raga, pengawasan dan control masyarakat terhadap pergaulan anak di masyarakat. Selanjuntya pihak desa juga telah melakukan tindakan untuk meningkatkan kegiatan remaja untuk aktif dan melakukan berbagai kegiatan olah 
raga dan kegiatan produktif lainnya dan membatasi serta mengawasi usaha internet yang ada di desa mitra. Selain itu juga pihak kecamatan kutalimbaru juga giat melakukan usaha peningkatan ekonomi dan kreatifitas masyarakat dengan berbagai materi pengetahuan yang disampaikan dari kecamatan kepada kader keluarga harapan di Desa Suka Dame. Semua usaha yang dilakukan oleh masyarakat, pihak pimpinan desa dan pimpinan kecamatan merupakan upaya dalam pencegahan tindak pidana pencabulan terhadap anak dan dampak terhadap anak.

\section{UCAPAN TERIMAKASIH}

Terima Kasih Kepada Lembaga Pengabidan Pada Masyarkat Universitas Sumatera Utara atas pendanaan Pengabdian ini berdasarkan kontrak, nomor Nomor: 327/UN5.2.3.2.1/PPM/2019, Tanggal 20 Mei 2019 tentang Pendidikan Hukum Pencegahan Tindak Pidana Pencabulan dan Dampak Pencabulan Terhadap Anak.

\section{DAFTAR PUSTAKA}

Atmasasmita Romli. 1983. Problem Kenakalan Anak-Anak Remaja. Armico: Bandung

Deliyana Shanty. 2001. Kenakalan Remaja. Sinar Grafika: Jakarta

Djamil, M. Nasir. 2013. Anak Bukan Untuk Dihukum, Catatan Pembahasan UU Sistem Peradilan Pidana Anak (UU-SPPA). Sinar Grafika: Jakarta

Departemen Pendidikan dan Kebudayaan. 1991. Kamus Besar Bahasa Indonesia. Balai Pustaka: Jakarta

Jasmine Sonia. (2016). Tindakan Hukum Terhadap Anak yang Melakukan Pencabulan, Jurnal.

Kartono, Kartini. 2014. Patologi Sosial 2: Kenakalan Remaja, PT Raja Grafindo Persada: Jakarta

Mamik, Purnianti, Sri Supatmi, \& Ni Made Martini Tinduk. (2003). mengutip Harry E. Allen and Clifford E. Simmonsen, dalam Correction in America: An Introduction, Analisa Situasi Sistem Peradilan Pidana Anak (Juvenile Justice System) di Indonesia, UNICEF, Indonesia.

Marpaung, Leden. 2004. Kejahatan Terhadap Kesusilaan dan Masalah Prevensinya. Sinar Grafika: Jakarta

Nashriana. 2012. Perlindungan Hukum Pidana Bagi Anak di Indonesia, PT Raja Grafindo Persada: Jakarta

Nassaruddin, Ende Hasbi. 2016. Kriminologi. CV Pustaka Setia: Bandung

Nurudin. 2017. Perkembangan Teknologi Komunikasi. PT RajaGrafindo Persada: Jakarta

Sudarsono. 2004. Kenakalan Remaja: Prevensi, Rehabilitasi, dan Resosialisasi. PT Rineka Cipta: Jakarta

Soesilo, R. 1994. Kitab Undang-Undang Hukum Pidana (KUHP) Serta Komentar-Komentarnya Lengkap Pasal Demi Pasal. Politeia: Bogor 
ISSN Printed Version: 2549-4341

Undang-Undang Nomor. 23 Tahun 2004 Tentang Pemberantasan Kekerasan Dalam Rumah Tangga.

Undang-Undang No. 11 Tahun 2012 tentang Sistem Peradilan Pidana Anak

Undang-Undang No. 35 Tahun 2014 tentang Perubahan Atas Undang-Undang No. 23 Tahun 2002 tentang Perlindungan Anak.

Undang-Undang No. 39 Tahun 1999 Tentang Hak Asasi Manusia

Wagiati Soetodjo. 2006. Hukum Pidana Anak. Refika Aditama: Bandung 